\title{
AKTIVITAS PENGHIMPUNAN DANA DEPOSITO \\ PADA PT. BANK PEMBANGUNAN DAERAH (BPD) SUMATERA BARAT CABANG LINTAU
}

\author{
Sri Vita Wahyuni, Afriyeni \\ Akademi Keuangan dan Perbankan Padang \\ Afriyeni.yen@gmail.com
}

\begin{abstract}
ABTRACT
This research explains about the accumulation of deposit fund at PT. Bank Pembangunan Daerah (BPD) West Sumatera Lintau Branch period 2013-2017. This study uses data collection techniques through library techniques and data collection through field studies. The analytical method used is qualitative data describes, understands and explains the amount of deposit data. The data used in this study is obtained from the financial statements of deposit funds for the period 2013-3017. Based on the results of research that has been done, the development of deposit funds from 2013 to 2017 shows an increase and decrease in amounts and deposits, in 2015 is the lowest amount of deposit funds and in 2017 is the highest amount of deposits.
\end{abstract}

Keyword: Deposit, Fund

\section{PENDAHULUAN}

Bank merupakan badan usaha yang tugas utamanya sebagai lembaga perantara keuangan (financial Intermediary), yang menyalurkan dana dari pihak yang berkelebihan dana kepada pihak yang membutuhkan dana atau kekurangan dana pada waktu yang ditentukan. Dana-dana bank bersumber dari modal sendiri, pinjaman dari pihak luar dan berupa simpanan dari pihak masyarakat. Sedangkan dana yang dihimpun oleh bank tersebut harus disalurkan kembali kepada masyarakat dalam bentuk kredit.

Bank pembangunan daerah secara umum adalah bank umum yang kepemilikan sahamnya dimiliki oleh pemerintah provinsi di berbagai daerah. Sebagai contoh Bank Pembangunan Daerah Provinsi Sumatera Barat yang kepemilikan sahamnya dimiliki oleh provinsi Sumatera Barat, disebut sebagai bank pembangunan daerah karena bank pembangunan daerah di tunjuk sebagai mitra kerja pemerintah untuk turut mendukung program kerja pemerintah provinsi yang membutuhkan layanan jasa keuangan dan perbankan.

Seperti layaknya bank umum Bank Pembangunan Daerah memiliki berbagai produk dan layanan untuk berbagai segmen masyarakat dan dunia usaha. Produk dana pihak ketiga terdiri dari tabungan, giro, dan deposito. Sedangkan untuk produk kredit dan pembiayaannya beragam, mulai dari kredit konsumtif seperti kredit tanpa agunan, perumahan, serta segmen produktif seperti modal usaha dan investasi. Secara umum, produk dan layanan bank pembangunan daerah tidak kalah dengan bank umum lainnya.

Kegiatan menghimpun dan menyalurkan dana merupakan kegiatan pokok bank sedangkan memberikan jasa bank lainnya hanya kegiatan pendukung. Kegiatan menghimpun dana, berupa mengumpulkan dana dari masyarakat dalam bentuk simpanan giro, tabungan, dan deposito. Pihak bank akan memberikan balas jasa yang 
menarik seperti, bunga dan hadiah sehingga masyarakat lebih senang menabung. Kegiatan menyalurkan dana, berupa pemberian pinjaman kepada masyarakat. Sedangkan jasa-jasa perbankan lainnya diberikan untuk mendukung kelancaran kegiatan utama tersebut.

Dana Pihak Ketiga (DPK) adalah pangsa pasar dana pihak ketiga yang dihimpun oleh masing-masing bank secara indvidu. Semakin tinggi rasio ini, maka semakin baik tingkat kepercayaan masyarakat terhadap bank yang bersangkutan. Adapun dana pihak ketiga diperoleh dengan menjumlahkan giro, tabungan dan deposito (Sudiyatno, 2008)

Deposito merupakan salah satu tempat bagi nasabah untuk melakukan investasi dalam bentuk surat-surat berharga. Kepada setiap deposan akan diberikan imbalan bunga atas depositonya. Bagi bank, bunga yang diberikan kepada deposan merupakan bunga yang tertinggi, jika dibandingkan dengan simpanan giro atau tabungan, sehingga deposito dianggap dana yang mahal bagi bank.

Deposito menurut Undang-Undang Nomor 10 Tahun 1998 adalah simpanan yang penarikanya hanya dapat dilakukan pada waktu tertentu berdasarkan perjanjian nasabah penyimpan dengan bank. Sedangkan menurut (Dendawijaya, 2005) adalah simpanan dari pihak ketiga kepada bank yang sistem penarikannya hanya bisa dilakukan dalam jangka waktu tertentu berdasarkan perjanjian antara pihak ketiga dengan bank yang bersangkutan.

Berikut ini perkembangan jumlah nasabah deposito dan saldo nominal deposito PT. Bank Pembangunan Daerah Sumatera Barat Cabang Lintau Periode 2013 s/d 2017.

Tabel 1

Perkembangan Jumlah Nasabah Deposito Dan Saldo Nominal PT. Bank Pembangunan Daerah Sumatera Barat Cabang Lintau

Tahun 2013 S/D 2017

\begin{tabular}{|c|c|c|}
\hline Tahun & $\begin{array}{c}\text { Jumlah nasabah } \\
\text { (orang) }\end{array}$ & $\begin{array}{c}\text { Saldo Nominal } \\
\text { (RP) }\end{array}$ \\
\hline 2013 & 155 & 8.743 .700 .000 \\
\hline 2014 & 134 & 8.298 .000 .000 \\
\hline 2015 & 115 & 8.051 .300 .000 \\
\hline 2016 & 148 & 10.480 .000 .000 \\
\hline 2017 & 134 & 11.164 .000 .000 \\
\hline
\end{tabular}

Sumber : PT. Bank Pembangunan Daerah Sumatera Barat Cabang Lintau, 2018

Berdasarkan latar belakang yang telah diuraikan diatas dengan meningkatnya jumlah deposito yang ada di PT. Bank Pembangunan Daerah Sumatera Barat Cabang Lintau mengalami kenaikan terus -menerus setiap tahunnya, maka dari itu penulis tertarik untuk melakukan penelitian dengan judul "Aktivitas Penghimpunan Dana Deposito Pada PT. Bank Pembangunan Daerah (BPD) Sumatera Barat Cabang Lintau". Perumusan Masalah

Berdasarkan latar belakang diatas maka perumusan masalah sebagai berikut : Bagaimana Aktivitas Penghimpunan Dana Deposito Pada PT. Bank Pembangunan Daerah (BPD) Sumatera Barat Cabang lintau?

Tujuan Penelitian

Penelitian ini adalah untuk mengetahui Aktivitas Penghimpunan Dana Deposito Pada PT. Bank Pembangunan Daerah (BPD) Sumatera Barat Cabang lintau.

\section{METODE PENELITIAN}

Dalam pengumpulan data dan bahan untuk melakukan penelitian ini digunakan metode-metode pengumpulan data terdiri dari :1) Riset Lapangan (Field Research)Peninjauan langsung ke objek penelitian untuk memperoleh data primer. 
Penelitian langsung kelapangan ini akan dapat membantu penulis untuk melengkapi datadata yang diperlukan. Adapun cara riset lapangan tersebut adalah dengan mewawancarai langsung ke pihak-pihak yang berkepentingan dalam hal ini adalah perusahaan atau instansi yang terkait. 2). Riset Perpustakaan (Library Research) Penelitian yang dilakukan ke perpustakaan berupa buku-buku ilmiah dan tulisan-tulisan yang berhubungan dengan pembahasan dilakukan.

Dalam menganalisa data, penulis menggunakan analisa data kualitatif. Data kualitatif adalah menggambarkan, memahami dan menjelaskan mengenai data yang diteliti selama penelitian.

\section{ANALISIS DAN PEMBAHASAN Pengertian Bank}

Menurut Undang-Undang Republik Indonesia No. 10 Tahun 1998 tentang Perbankan, "Bank adalah badan usaha yang menghimpun dana dari masyarakat dalam bentuk simpanan dan menyalurkannya dalam bentuk kredit dan atau bentuk-bentuk lainnya dalam rangka meningkatkan taraf hidup rakyat banyak. Bank umum adalah bank yang melaksanakan kegiatan usaha secara konvensional dan atau berdasarkan prinsip syariah yang dalam kegiatannya memberikan jasa dalam lalu lintas pembayaran. Bank Perkreditan Rakyat adalah bank yang melaksanakan kegiatan usaha secara konvensional atau berdasarkan prinsip syariah yang dalam kegiatannya tidak memberikan jasa dalam lalu lintas pembayaran".

Bank secara sederhana menurut Kasmir (2011) adalah "Lembaga keuangan yang kegiatan utamanya adalah dengan menghimpun dana dari masyarakat dan menyalurkannya kembali dana tersebut ke masyarakat serta memberikan jasa bank lainnya." Abdullah (2000) mendefinisikan bank sebagai berikut "bank merupakan bagian dari lembaga keuangan yang memiliki fungsi intermediasi yaitu menghimpun dana dari masyarakat yang kelebihan dana dan menyalurkan dana yang dihimpunnya kepada masyarakat yang kekurangan dana."

\section{Fungsi Bank}

Menurut Santoso (2012) secara umum fungsi utama bank adalah menghimpun dana dari masyarakat dan menyalurkannya kembali kepada masyarakat untuk berbagi tujuan atau sebagai Financial Intermediary. Secara spesifik fungsi utama bank adalah:1) Agent of Trust, dasar utama kegiatan perbankan adalah kepercayaan (trust), baik dalam hal penghimpunan dana maupun penyaluran dana. 2) Agent of Development, Kegiatan perekonomian masyarakat di sektor moneter dan di sektor riil tidak dapat dipisahkan. Kedua sektor tersebut selalu berinteraksi dan saling mempengaruhi. Sektor riil tidak akan dapat berkinerja dengan baik apabila sektor moneter tidak bekerja dengan baik. 3) Agent of Service, Di samping melakukan kegiatan penghimpunan dan penyaluran dana, bank juga memberikan penawaran jasa perbankan yang lain kepada masyarakat. Jasa yang ditawarkan bank ini erat kaitannya dengan kegiatan perekonomian masyarakat secara umum. Jasa ini antara lain dapat berupa jasa pengiriman uang, penitipan barang berharga, pemberian jaminan bank, dan penyelesaian tagihan.

\section{Jenis-Jenis Bank}

Menurut Fransiska (2013) perbedaan jenis perbankan dapat dilihat dari segi fungsi, kepemilikan dan dari segmen mentukan harga. Dari segi fungsi perbedaan yang terjadi terletak pada luasnya kegiatan atau jumlah produk yang dapat ditawarkan maupun jangkauan wilayah operasinya. Kemudian kepemilikan perusahaan dilihat dari segi pemilikan saham yang ada serta akta pendiriannya. Sedangkan dari menentukan harga, yaitu antara bank konvensional berdasarkan bunga dan bank syariah berdasarkan bagihasil. Untuk lebih jelasnya jenis perbankan dewasa ini dapat ditinjau dari berbagai 
segi antara lain: a.Dilihat dari Segi Fungsi, dibagi menjadi:

1) Bank Umum, adalah bank yang melaksanakan kegiatan usaha secara konvensional dan/atau berdasarkan prinsip syariah yang dalam kegiatannya memberikan jasa dalam lalu lintas pembayaran.

2) Bank Perkreditan Rakyat (BPR), adalah bank yang melaksanakan kegiatan usaha secara konvensional atau berdasarkan prinsip syariah yang dalam kegiatannya tidak memberikan jasa dalam lalu lintas pembayaran.

a. Dilihat dari Segi Kepemilikan, dibagi menjadi:

1) Bank Milik Pemerintah, yaitu di mana baik akta pendirian maupun modalnya dimiliki oleh pemerintah, sehingga seluruh keuntungan bank ini dimiliki oleh pemerintah pula. Sedangkan Bank Milik Pemerintah Daerah, yaitu di mana akta pendirian maupun modal bank sepenuhnya dimiliki oleh pemerintah daerah, sehingga keuntungan bank dimiliki oleh pemerintah daerah.

2) Bank Milik Swasta Nasional, merupakan bank yang seluruh atau sebagian besarnya dimiliki oleh swasta nasional serta akta pendiriannya pun didirikan oleh swasta, begitu pula pembagian keuntungannya diambil oleh swasta pula. Bank-bank swasta milik nasional termasuk pula bank-bank yang dimiliki oleh badan usaha yang berbentuk koperasi.

3) Bank Milik Asing, merupakan cabang dari bank yang ada di luar negeri, baik milik swasta asing maupun pemerintah asing suatu negara.

4) Bank Milik Campuran, merupakan bank yang kepemilikan sahamnya dimiliki oleh pihak asing dan pihak swasta nasional.

b. Dilihat dari Segi Status, dibagi menjadi:

1) Bank Devisa merupakan bank yang dapat melaksanakan transaksi ke luar negeri atau yang berhubungan dengan mata uang asing secara keseluruhan.

2) Bank Non Devisa merupakan bank yang belum mempunyai izin untuk melakukan transaksi sebagai bank devisa, sehingga tidak dapat melaksanakan transaksi.

c. Dilihat dari Segi Cara Menentukan Harga, dibagi menjadi:

1) Bank yang berdasarkan prinsip konvensional yaitu bank yang dalam mencari keuntungan dan menentukan harga kepada nasabahnya menggunakan metode penetapan bunga sebagai harga jual, demikian pula harga beli ditentukan berdasarkan tingkat suku bunga tertentu. Penentuan harga ini dikenal dengan istilah spread based dan sistem pengenaan biaya untuk jasa-jasa bank lainnya dikenal dengan istilah feebased.

2) Bank yang berdasarkan prinsip syariah yaitu bank yang dalam mencari keuntungan dan menentukan harga berdasarkan prinsip syariah adalah pembiayaan berdasarkan prinsip bagi hasil (mudharabah), prinsip penyertaan modal (musharakah), prinsip jual beli barang dengan memperoleh keuntungan (murabahah), pembiayaan barang modal berdasarkan sewa murni tanpa pilihan (ijarah), atau dengan adanya pilihan pemindahan kepemilikan atau barang yang disewa dari pihak bank kepada pihak lain (ijarah waiqtina).

\section{Sumber Dana Bank}

Pengertian sumber dana bank adalah usaha bank dalam menghimpun dana dari masyarakat Kasmir (2011). Dalam menghimpun dana tersebut, sudah tentu bank harus mengenal sumber-sumber dana yang terdapat di dalam berbagai lapisan 
masyarakat dengan bentuk yang berbeda-beda pula. Secara garis besar sumber dana bank dapat diperoleh dari:

1. Bank itu sendiri, perolehan dana dari sumber bank itu sendiri (modal sendiri) maksudnya adalah dana yang diperoleh dari dalam bank. Adapun pencarian dana yang bersumber dari bank itu sendiri terdiri dari:

a. Setoran modal dari pemegang saham, yaitu merupakan modal dari para pemegang saham lama atau pemegang saham baru.

b. Cadangan laba, yaitu merupakan laba yang setiap tahun dicadangkan oleh bank dan sementara waktu belum digunakan.

c. Laba bank yang belum dibagi, merupakan laba tahun berjalan tapi belum dibagikan kepada para pemegang saham.

2. Masyarakat luas, sumber dana ini merupakan sumber dana terpenting bagi kegiatan operasi bank dan merupakan ukuran keberhasilan bank jika mampu membiayai operasi sumber dana ini. Untuk memperoleh dana dari masyarakat luas bank dapat menggunakan tiga jenis simpanan (rekening). Sumber dana yang dimaksud adalah sebagai berikut:

a. Simpanan Giro

b. Simpanan Tabungan

c. Simpanan Deposito

Pembagian jenis simpanan kedalam beberapa jenis dimaksudkan agar para penyimpan mempunyai pilihan sesuai dengan tujuan masing-masing.

3. Dana yang bersumber dari lembaga lain, merupakan tambahan jika bank mengalami kesulitan dalam pencarian sumber dana dari bank itu sendiri dan masyarakat luas. Perolehan dana dari sumber ini antara lain dapat diperoleh dari:

a. Bantuan Likuiditas Bank Indonesia (BLBI), merupakan dana yang diberikan Bank Indonesia kepada bank-bank yang mengalami kesulitan likuiditasnya.

b. Pinjaman antar bank (Call Money). Biasanya pinjaman ini diberikan kepada bank-bank yang mengalami kalah kliring di dalam lembaga kliring dan tidak mampu untuk membayar kekalahannya.

c. Pinjaman dari bank-bank luar negeri, merupakan pinjaman yang diperoleh perbankan dari pihak luar negeri.

d. Surat Berharga Pasar Uang (SBPU), dalam hal ini pihak perbankan menerbitkan SBPU kemudian diperjual belikan kepada pihak yang berminat, baik perusahaan keuangan maupun non keuangan.

\section{Pengertian Deposito}

Deposito merupakan suatu produk bank yang mirip dengan jasa tabungan yang ditawarkan kepada masyarakat. Deposito adalah produk penyimpanan uang di bank dengan sistem setoran yang penarikannya hanya bisa dilakukan sesudah melewati waktu tertentu. Dana dalam deposito dijamin oleh pemerintah melalui Lembaga Penjamin Simpanan yang mempunyai syarat tertentu.

Menurut Prilliana (2014) sadalah simpanan pihak ketiga pada pihak bank yang hanya bisa dilakukan penarikan sesuai dengan jangka waktu yang telah ditentukan menurut perjanjian oleh pihak ketiga dan pihak bank. Sedangkan menurut Sahabudin (2005) simpanan yang penarikannya hanya dapat dilakukan pada waktu tertentu beradasarkan perjanjian nasabah penyimpanan dengan baik. 
1. Fungsi Deposito

Fungsi dari deposito menurut Andryani (2012) mempunyai dua fungsi, yaitu:

a. Fungsi Intern

Fungsi intern merupakan fungsi strategis dalam membantu aktivitas operasional bank dengan ruang lingkup khusus bank itu sendiri. Jenis simpanan ini adalah salah satu sumber utama modal bank yang mudah pemakaiannya karena memiliki limit waktu. Deposito untuk sebuah bank fungsinya sebagai pemenuh kebutuhan modal bank, dan disisi lain juga membantu menjaga posisi likuiditas bank. Keperluan terhadap modal kerja sebuah bank harus selalu dipenuhi setiap saat sehubungan dengan salah satu fungsi yang utama yaitu sebagai lembaga yang menyalurkan dana dari masyarakat berupa kredit atau sebagai lembaga pemberi kredit.

b. Fungsi Ekstern

Fungsi ekstern berhubungan dengan fungsi yang berada diluar perusahaan bank yaitu sebagai lembaga yang pergerakannya pada bidang jasa yang mempermudah arus pembayaran uang. Dalam usaha mencapai tujuan pembangunan nasional diharapkan lembaga perbankan bisa berperan dalam mendorong meningkatnya pertumbuhan ekonomi dan stabilitas nasional kearah peningkatan perkembangan perekonomian nasional ataupun internasional yang selalu bergerak cepat dan juga diikuti tantangan yang bertambah luas.

Deposito adalah jalan penghimpunan dana dalam jumlah yang besar, dengan demikian pemerintah sangat mengharapkan inisiatif dari masyarakat untuk menanamkan dana yang lebih ini lewat deposito demi menujang pembangunan yang selalu memerlukan dana yang sangat besar.

\section{Analisa dan Pembahasan Aktivitas Penghimpunan Dana Deposito pada PT. Bank Pembangunan Daerah (BPD) Sumatera Barat Cabang Lintau}

Deposito (Time Deposito) merupakan salah tempat bagi nasabah untuk melakukan transaksi dalam bentuk surat-surat berharga. Pemilik deposito disebut deposan. Kepada setiap deposan akan diberikan imbalan bunga atas depositonya. Bagi bank, bunga yang diberikan kepada para deposan, merupakan bunga yang tertinggi. Jika dibandingkan dengan simpanan giro atau tabungan. Sehingga deposito oleh sebagian bank adalah sebagai dana modal.

Keuntungan bank dengan menghimpun dana lewat deposito adalah uang yang tersimpan bisa lebih lama, mengingat deposito memiliki jangka waktu yang relative panjang dan frekuensi penarikan juga jarang. Dengan demikian bank dapat dengan leluasa untuk menggunakan kredit dana tersebut.

Deposito menurut UU No.10 tahun 1998, Pasal 1 ayat 7 (1998:7) yang memberikan pengertian deposito adalah "Simpanan yang penarikannya hanya dapat dilakukan pada waktu tertentu berdasarkan perjanjian nasabah penyimpan dengan bank".

\section{Jenis Jenis Deposito}

a. Deposito Berjangka

Deposito berjangka merupakan deposito yang diterbitkan menurut jangka waktu yang tertentu. Jangka waktu deposito biasanya bervariasi mulai dari 1, 3, 6, 12, 18 sampai dengan 24 bulan. Deposito berjangka diterbitkan atas nama baik perorangna maupun lembaga. Artinya didalam bilyet deposito tercantum nama seseorang atau lembaga. 
Kepada setiap deposan diberikan bunga yang besarnya sesuai dengan berlakunya bunga pada saat deposito berjangka dibuka. Pencairan bunga deposito dapat dilakukan setiap bulan atau setelah jatuh tempo. Penarikan dapat dilakukan dengan tunai maupun non tunai (pemindahbukuan). Kepada setiap deposan dikenakan pajak terhadap bunga yang diterimanya.

Deposito berjangka juga memiliki batas minimal yang harus disetor yang besarnya tergantung bank yang mengeluarkannya. Untuk menarik minat para deposan biasanya bank menyediakan berbagai insentif tertentu atau bonus. Insentif diberikan untuk jumlah nominal tertentu biasanya dalam jumlah yang besar. Insentif dapat berupa, bunga lebih tinggi dari bunga yang berlaku umum, maupun insentif lainnya, seperti hadiah atau cendramata lainnya. Insentif juga dapat diberikan kepada nasabah yang loyal terhadap bank tertentu.

Disamping diterbitkan dalam mata uang rupiah deposito berjangka yang diterbitkan dalam valuta asing (valas). Deposito berjamgka terdiri dari :

1) Deposito Automatic Roll Over

Deposito berjangka yang berlaku terus secara otomatis walaupun jangka waktu yang telah ditetapkan sudah habis. Misalnya suatu deposito berjangka 1 bulan jatuh tempo pada tanggal 10 februari 2018, jika pada tanggal tersebut tidak ditarik oleh deposan, maka Bank Pembangunan Daerah Sumatera Barat secara otomatis akan memperpanjang deposito tersebut untuk sebulan berikutnya, dengan tingkat bunga yang berlaku pada saat perpanjangan. Jumlah dana yang didepositokan adalah pokok deposito ditambah dengan bunga periode sebelumya.

2) Deposito Non Automatic Roll Over

Deposito berjangka yang tidak diperpanjang oleh bank jika deposito tersebut telah jatuh tempo tapi belum dicairkan oleh pemiliknya, walaupun deposito tetap berada di bank deposan tidak mendapat bunga.

b. Sertifikat Deposito

Merupakan deposito yang diterbitkan dengan jangka waktu 1, 3, 6, 12 bulan. Sertifikat deposito yang diterbitkan atas unjuk dalam bentuk sertifikat. Artinya didalam sertifikat nama seseorang atau badan hukum tertentu. Disamping itu sertifikat deposito dapat diperjualbelikan pada pihak lain. Pencairan bunga sertifikat dapat dilakukan dimuka, tiap bulan atau jatuh tempo, baik tunai maupun non tunai. Dalam praktiknya kebanyakan deposan mengambil bunga dimuka.

Penerbitan nilai sertifikat depostio sudah tercetak dalam berbagai nominal dan biasanya dalam jumlah bulat. Sehingga nasabah dapat membeli dalam lembaran banyak untuk jumlah nominal yang sama.

\section{c. Deposito On Call}

Merupakan deposito yang berjangka waktu minimal 7 hari dan paling lama kurang dari 1 bulan. Diterbitkan atas nama dan biasanya dalam jumlah yang besar misalnya 50 juta rupiah (tergantung bank yang bersangkutan). Pencairan bunga dilakukan pada saat pencairan deposit on call dan sebelum deposit on call dicairkan terlebih dahulu 3 hari sebelumnya nasabah sudah memberitahukan bank penerbit. Besarnya bunga biasanya dihitung per bulan dan biasanya untuk menentukan bunga dilakukan negosiasi antara nasabah dengan pihak bank.

\section{Prosedur Pembukaan Rekening Deposito}

Pembukaan deposito pada PT. Bank Pembangunan Daerah (BPD) Sumatera Barat Cabang Lintau yang pertama adalah nasabah mengajukan permohonan membuka rekening yang di catat oleh bank sehingga nasabah 
tersebut mempunyai nomor rekening deposito. Setelah mempunyai nomor rekening di bank, nasabah dapat menyetorkan dananya pada bank pembangunan daerah dengan jangka waktu penyimpanan sesuai dengan permohonan nasabah baik dalam jangka 1, 3, 6, 12, 18 sampai dengan 24 bulan.

a. Syarat-syarat pembukaan deposito :

1) Mengisi aplikasi permohonan pembukaan deposito

2) Foto copy KTP/ SIM/ paspor (WNA)

3) Jumlah minimal untuk nominal yang di depositokan Rp 1 Juta (US\$ 5000) atau dengan kebijaksanaan setiap bank

4) Besarnya bunga yang diberikan

5) Cara pembayaran bunga

6) Cara pencairan deposito

7) Perpanjangan deposito secara otomatis/Automatic Roll-Over (ARO)

b. Ketentuan Deposito

1) Mata uang dalam rupiah dan valuata asing

2) Bunga dapat diambil setiap bulan atau dipindahbukukan ke rekening tabungan nasabah

3) Jangka waktu dapat dipilih

1) 1 bulan

2) 3 bulan

3) 6 bulan

4) 12 bulan

5) 24 bulan

4) Dapat diperpanjang secara otomatis

c. Manfaat

1) Bunga menarik dan bersaing

2) Dijamin LPS sampai dengan 2 Miliar dengan bunga maksimal sebesar suku bunga LPS

3) Dapat dijadikan jaminan kredit (Back to Back)

4) Persyaratan mudah dan transparan

\section{Alur Proses Penarikan Deposito Tunai}

\section{a. Melalui Kantor Bank}

1) Nasabah datang ke kantor bank dengan membawa bilyet

2) Customer Service mengontrol bilyet yang telah jatuh tempo dan memberikan penjelasan kepada nasabah serta melengkapi segala persyaratan administrasi setelah lengkap diserahkan kepada kasir

3) Kasir memvalidasi dan mendebet saldo deposito serta langsung menyerahkan kepada nasabah

4) Proses diatas memerlukan waktu maximal 20 menit

\section{Aktivitas Penghimpunan Dana Deposito}

Penghimpunan dana merupakan suatu kegiatan usaha yang dilakukan bank pembangunan daerah untuk mencari dana kepada pihak deposan yang nantinya akan disalurkan kepada pihak kreditur dalam rangka menjalankan fungsinya sebagai intermediasi antara pihak deposan dengan pihak kreditur. Perkembangan dan tingkat pertumbahan penghimpunan dana deposito pada PT. Bank Pembangunan Daerah Sumatra Barat Cabang Lintau dapat dilihat pada tabel di bawah ini: 
Tabel 2

Perkembangan Jumlah Dana Deposito

PT. Bank Pembangunan Daerah (BPD) Sumatra Barat Cabang Lintau

Tahun 2013 S/D 2017

\begin{tabular}{|c|c|c|}
\hline Tahun & Jumlah Deposito (Rp) & Persentase \\
\hline 2013 & 8.743 .000 & $7,36 \%$ \\
\hline 2014 & 8.298 .000 & $6,98 \%$ \\
\hline 2015 & 8.051 .300 & $67,41 \%$ \\
\hline 2016 & 10.480 .000 & $8,82 \%$ \\
\hline 2017 & 11.164 .000 & $9,40 \%$ \\
\hline Total & $\mathbf{1 1 8 . 7 3 7 . 0 0 0}$ & $\mathbf{1 0 0 \%}$ \\
\hline
\end{tabular}

Dari tabel diatas penghimpunan dana deposito pada PT. Bank Pembangunan

Daerah Sumatera Barat Cabang Lintau dari tahun 2013-2017 mengalami peningkatan, mulai dari dana deposito pada tahun $2013 \mathrm{Rp}$. 8.743.700.000, akan tetapi tahun 2015 dana deposito menurun sebesar Rp. 8.051.300.000, dan tahun 2016 sampai tahun 2017 dana deposito terus meningkat dengan jumlah terhimpun sebesar Rp. 11.164.000.000, hal ini membuktikan bahwa PT. Bank Pembangunan Daerah (BPD) Sumatera Barat Cabang Lintau mampu dalam menarik nasabah untuk menitipkan dananya di bank tersebut, sehingga dengan adanya dana yang terhimpun dari deposito yang cukup baik dan terus meningkat, maka masyarakat yang kekurangan dana pun bisa untuk meminjam dana untuk keperlssssuan usaha ataupun untuk komsumsi dalam kehidupan sehari -hari, dan nasabah yang menghimpun dana akan mendapatkan bunga yang telah di sepakati antara nasabah dengan bank, dan Bank Pembangunan Daerah (BPD) Sumatra Barat Cabang Lintau pun akan memperoleh bunga dari hasil kredit yang disalurkannya kepada masayakat.

Dari keterangan diatas dapat disimpulkan bahwa PT. Bank Pembangunan Daerah (BPD) Sumatera Barat Cabang Lintau dalam melakukan transaksi tidak membedakan calon nasabah yang akan di layani, dan bank juga transparan dalam memberikan keterangan yang menyakut dengan deposito yang di sediakannya, serta lebih menanamkan kepercayaan kepada calon nasabah.

\section{SIMPULAN}

Deposito merupakan simpanan pihak ketiga kepada bank yang penarikannya hanya dapat dilakukan setelah jangka waktu tertentu menurut perjanjian antar nasabah dengan pihak yang bersangkutan yang melakukan deposito (deposan). Deposito yang ditawarkan oleh bank terdiri dari, deposito berjangka, sertifikat deposito, dan deposit on callbaik dalam mata uang rupiah maupun mata uang asing. Deposito memiliki jangka waktu, pada PT. Bank Pembangunan Daerah (BPD) Sumatera Barat Cabang Lintau deposito terdiri dari satu bulan, tiga bulan, enam bulan, dua belas bulan, delapan belas bulan, dan dua puluh empat bulan. Dari penelitian yang telah dilakukan di PT. Bank Pembangunan Daerah (BPD) Sumatera Barat Cabang Lintau maka dapat di peroleh hasil sebagai berikut :1) syarat dan ketentuan saat pembukaan deposito, yaitu harus mempunyai rekening di PT. Bank Pembangunan Daerah (BPD) Sumatera Barat Cabang Lintau baik tabungan maupun giro, lalu mengisi dan menandatangani form aplikasi penyetoran deposito berjangka rupiah. Deposan harus menyerahkan dokumen pendukung seperti, $\mathrm{KTP} / \mathrm{SIM}$ /Paspor yang masih berlaku bagi perorangan. 2)prosedur perpanjangan jangka waktu deposito secara otomatis menggunakan Autometic Roll Over (ARO), maupun langsung datang ke bank untuk melakukan perpanjangan.3) jenis deposito di PT. Bank Pembangunan Daerah (BPD) Sumatera Barat Cabang Lintau ada tiga jenis yaitu, Deposito berjangka, Sertifikat deposito, dan deposito on call dengan jangka waktu 1, 3, 
$6,12,18$, dan 24 bulan.4) perkembangan jumlah deposito dari tahun 2013 sampai tahun 2017 terjadi peningkatan dan penurunan jumlah dana deposito, deposito terendah tahun 2015 dengan jumlah deposito sebesar Rp. 8.051.300.000,- dan jumlah deposito tertinggi pada tahun 2017 dengan jumlah deposito sebesar Rp. 11.164.000.000,-.

\section{UCAPAN TERIMA KASIH}

Dengan menyebut nama Allah SWT yang Maha Pengasih lagi Maha Penyayang, penulis ucapkan puji dan syukur atas kehadirat-Nya, yang telah melimpahkan rahmat, hidayahNya kepada saya.penulis ingin menyampaikan terima kasih yang tak terhingga atas bimbingan ibuk Afriyeni, SE,MM yang telah memberikan motivasi, masukanmasukan maupun kritik-kritik dan dukungan secara moril ataupun material dan untuk sahabat terbaik terimaksih untuk semangat dan dukungannya yang sangat berguna untuk Tugas Akhir. Akhir kata penulis ucapkan terimah kasih, semoga apa yang penils tuangkan dalam karya kecil ini memberikan manfaat terutama bagi saya sendiri selaku penulis. Amin ya Rabbal'alamin.

\section{DAFTAR PUSTAKA}

Abdullah. Analisis Faktor-faktor yang Mempengaruhi Penghimpunan Deposito Mudharabah Perbankan Syariah di Indonesia. 2000;11(4):595-604.

Andryani. Analisis Pengaruh Return on Asset, BOPO, dan Suku Bunga Terhadap Tingkat Bagi Hasil Deposito Mudharabah pada Bank Umum Syariah. J Ekon dan Bisnis. 2012;11(1):29-42.

Fransiska. Perbandingan Kinerja Keuangan Bank Mandiri, BRI Dan BNI Yang Terdaftar Di Bursa Efek Indonesia. 2013;3:782-792.

Hidayati, R. R., \& Marlius, D. (2018). Aktivitas Promosi Dalam Meningkatkan Dana Pihak Ketiga Pada PT. Bank Perkreditan Rakyat (BPR) Batang Kapas Pesisir Selatan. https://doi.org/10.31227/osf.io/8dgqn

Kasmir. Analisis tingkat kecukupan modal dan Loan to Deposit Ratio terhadap profitabilitas. dasar-dasar Perbankan. 2002;4(2):114-125.

Lukman dendawijaya. Manajamen Lembaga Keuangan. J Akunt. 2005;5:7.

Marlius, D. (2016). Pengaruh Bauran Pemasaran Jasa Terhadap Minat Nasabah Dalam Menabung Pada Bank Nagari Cabang Muaralabuh. https://doi.org/10.31227/osf.io/vdqgx

Prilliana. 2014. “Analisis Perkembangan Giro Tabungan dan Deposito Di PT Bank Sulut, 16.

Rahayu. Pengaruh Modernisasi Sistem Administrasi Perpajakan terhadap Kepatuhan Wajib Pajak (Survei atas Wajib Pajak Badan pada KPP Pratama Bandung " $\mathrm{X}$ ” ). 2009;1(2):119-138.

Sahabudin. Stabilitas Permintaan Uang di Indonesia: Sebelum dan Sesudah Perubahan Sistem 
Nilai Tukar. 2005;10(1):31-41.

Sudiyatno, Pengaruh Dana Pihak Ketiga, Kecukupan Modal, Risiko Kredit Dan Suku Bunga Kredit Pada Profitabilitas, 9.1 (2014): 27-38

Susanti, F. W Ekazaputri. (2018). Service Performance Dan Kepuasan Sebagai Moderating Variabel Terhadap Loyalitas Nasabah Pada PT BPR Labuh Gunung Payakumbuh Jurnal Benefita: Ekonomi Pembangunan Manajemen Bisnis Dan Akuntansi. Volume 3. No. 3. Hal. 433-444.http://doi.org/10.22216/jbe.v3i3.3472

Undang-Undang No. 10 Tahun 1998 Tentang Perubahan Tentang Undang- Undang No. 7 Tahun 1992 Tentang Perbankan

Wardani. Analisis Pengaruh Jumlah Dana Pihak Ketiga (DPK), Non Performing Financing (NPF) Dan Tingkat Inflasi Terhadap Total Pembiayaan Yang Diberikan Oleh Bank Pembiayaan Rakyat Syariah (BPRS) Di Indonesia.

Widayati, R. (2019). Promotional Activities And Services Bank Nagari Kambang Increase In Customer. https://doi.org/10.17605/OSF.IO/MYAVT

Widayati, R. (2019). Aktivitas Pemasaran Produk Simpanan PT. Bank Tabungan Negara (Persero)Tbk Kantor Cabang Padang. https://doi.org/10.17605/OSF.IO/3Z5YC

Widayati, R. (2019). Aktivitas Pemasaran Produk Tabungan Pada PT. Bpr Rangkiang Denai Payakumbuh Barat. https://doi.org/10.17605/OSF.IO/S3UZM 